\title{
Morphological Indices and Carcass Measurements of Indigenous Breeds of Rams Intensively Fattened
}

\author{
Akinleye Sule Bamidele ${ }^{1, ~ *, ~ L u k a ~ S a b o ~ J a m e s ², ~ A f o l a b i ~ K o l a w o l e ~ D a n i e l ~}{ }^{3}$, \\ Akinsola Saheed Olatunde ${ }^{3}$, Adeyemi Saheed Abimbade ${ }^{4}$ \\ ${ }^{1}$ Department of Animal Science, University of Ibadan, Ibadan, Nigeria \\ ${ }^{2}$ Department of Animal Science, University of Jos, Jos, Nigeria \\ ${ }^{3}$ Department of Animal Science, University of Uyo, Uyo, Nigeria \\ ${ }^{4}$ Department of Animal Science, Al-Hikmah University, Ilorin, Nigeria
}

Email address:

bamideleakinleye@yahoo.com(A. S. Bamidele)

${ }^{*}$ Corresponding author

\section{To cite this article:}

Akinleye Sule Bamidele, Luka Sabo James, Afolabi Kolawole Daniel, Akinsola Saheed Olatunde, Adeyemi Saheed Abimbade. Morphological Indices and Carcass Measurements of Indigenous Breeds of Rams Intensively Fattened..Animal and Veterinary Sciences. Special Issue: Promoting Animal and Veterinary Science Research. Vol. 8, No. 5, 2020, pp. 110-116. doi: 10.11648/j.avs.20200805.14

Received: May 26, 2020; Accepted: July 22, 2020; Published: September 28, 2020

\begin{abstract}
Growth rate assessment is an important husbandry practice often carried out in livestock breeding and fattening. Meat production is the most important trait in the breeding objectives of sheep production. Useful information on the suitability of the animals for meat production could be evaluated on a morphological basis. The aim of this study was to investigate breed differences in liveweight, carcass traits and muscle distribution for meat characteristics among Balami (BA), Uda (UD), Yankasa (YK) and West African Dwarf rams (WAD). A total of forty-eight rams were randomly assigned into four groups of twelve rams per breed in a completely randomized design. Body linear measurements were obtained weekly during the fattening period. At the end of the feeding trial, animals were subjected to an 18-hours fast and slaughtered for carcass measurements and muscle distribution. Results showed that BA and UD had higher values for body length (115.75 \pm 4.25 and $110.25 \pm 1.89 \mathrm{~cm})$, withers height $(70.50 \pm 5.57 \mathrm{and} 69.00 \pm 2.16 \mathrm{~cm})$ and heartgirth $(92.00 \pm 2.94 \mathrm{and} 84.00 \pm 1.41 \mathrm{~cm})$, than $\mathrm{YK}$ $(96.50 \pm 3.87,60.75 \pm 3.30$ and $76.75 \pm 0.96 \mathrm{~cm})$, respectively which in turn had higher values than WAD $(86.50 \pm 5.20,53.25 \pm 5.32$ and $75.25 \pm 3.30 \mathrm{~cm}$ ). Carcass length, pistol length, and leg length were 75.75 $\pm 4.79,60.75 \pm 7.14$ and $88.00 \pm 2.16 ; 75.50 \pm 4.66$, $56.00 \pm 5.00$ and $80.25 \pm 5.80 ; 59.00 \pm 7.79,56.00 \pm 10.62$ and $71.50 \pm 2.65 ; 60.50 \pm 3.11,53.75 \pm 5.91$ and $61.00 \pm 2.94 \mathrm{~cm}$ for BA, UD, YK and WAD rams, respectively. BA and UD had higher proportion of muscle distribution and were generally better than the YK and WAD breeds. This may boost their potential for large scale meat production under fattening conditions.
\end{abstract}

Keywords: Hindquarter, Meat, Fattening, Carcass, Pistola, Muscle Distribution

\section{Introduction}

Nigeria's livestock industry is small and slow-growing relative to the population relying on it for meat [1]. Farmers need to invest in breeds that have traits for good carcass quality.The breed that can deliver good quality meat should be selected or bred for important and desirable traits. The commercial value of meat animals is determined by the carcass weight, proportion, and distribution of carcass muscle [2]. The use of specialized meat breeds to improve animal productivity and economic results is desirable in intensive sheep production. The quality of rams of local breeds is an important instrument to promote the consumption of meat in the local population [3]. Morphometric measurements have been used to evaluate the characteristics of various breeds of animals and could provide first-hand information on the suitability of animals for selection [4]. Based on body conformation, meat production can better be estimated than other production properties, making body measurements important selection criteria [5]. Muscularity indicates the amount of muscle tissue, determined by muscle to bone ratio and fatness describes the external and internal deposition of 
fat in the carcass. According to Srivastava et al. [6], body measurements are indices of skeletal development and indirectly help to determine carcass composition. Another parameter that has been used over the years to estimate the amount of meat that could be obtained from slaughtered animals is carcass measurement. Carcass composition assessment assigns value, sorting of carcasses for further processing and transfers information back to the production sector, ensuring that carcasses meet consumer demand. The objectives of the present study were to analyze the interrelationships between weights and measurements of carcasses; compare various measurements of the body, carcass, and tissue distribution for BA, UD, YK and WAD breeds of ram under intensive management.

\section{Materials and Methods}

\subsection{Location of Experiment}

The study was conducted at the Sheep and Goat unit of the Teaching and Research Farm, University of Ibadan, located on Latitude $7^{\circ} 26^{\prime} \mathrm{N}$ and $3^{\circ} 54^{\prime} \mathrm{E}$ and on an elevation of $330 \mathrm{~m}$ above sea level. The area is characterized by humid tropical climate with an annual rainfall of $1540 \mathrm{~mm}$ and an average temperature of $22.1^{\circ} \mathrm{C}$ to $30.8^{\circ} \mathrm{C}$ for ten-hours per day

\subsection{Animal Management}

Forty-eight rams of Balami (BA), Uda (UD), Yankasa (YK) and West African Dwarf (WAD) breeds. Weighing $17.00 \pm 0.39-19.38 \pm 0.39$ (12-18months of age). The age of the animals was estimated by visual observation, interviewing the owners and by dentition. Four breeds of rams (Twelve replicate per breed) were raised intensively. The rams were dewormed (300mg albendazole bolus for internal and with acarimic spray for external parasites, respectively), dipped and vaccinated against known parasites and diseases during the period of twenty-one days and were adapted for 15 days followed by ninety days feeding period. Experimental animals were fattened for ninety days, during which time each pen of rams was supplied with concentrate (14\% crude protein and $2.00 \mathrm{Mcal} / \mathrm{kg}$ digestible energy) and hay at the rate $5 \%(60: 40)$ of the body weight per ram and adlibtum access to salt lick and fresh, clean and cool water. At the end of the ninety days, four rams in each group whose weights were the closest to the average final weight of the rams of respective breeds were chosen for subsequent carcass analysis.

\subsection{Linear Body Measurements}

The six morphometric traits measured were wither height, pelvis height, body length, heart girth, chest width, and chest depth. Measurement was done using a graduated measuring stick. To achieve this, animals were placed on flat ground and held by two field assistants. The length measurements were done using a Dalton's weighing band tape rule while the width measurements were taken using a calibrated wooden caliper [7]. The following body measurements were estimated:

1) Body length: the distance between the point of shoulder and the pin-bone.

2) Height at withers: vertical distance from the withers to the floor.

3) Heart girth: circumference of the body just behind the fore legs

4) Chest depth: vertical distance from the withers to the chest bottom,

5) Chest width: width of the body at the withers.

6) Height at Pelvic: hind leg length between malleolus and perineeum

\subsection{Slaughter Procedure}

The selected rams (four rams per breed) were transported to the slaughter house of the Department of Animal Science, University of Ibadan where pre-slaughter liveweight was recorded after twelve-hours of fasting but free access to water. Exsanguination was carried out by an incision on the jugular furrow at the occipital-atlantal junction close to the head, severing the carotid arteries, jugular veins, trachea, oesophagus, and the spinal cord. The head was removed and the carcass was hung by the hindlegs using a pulley and then skinned [8].

\subsection{The Evisceration of Carcasses and Carcass Evaluation}

Evisceration was carried out and hot carcass weight was taken on the slaughter floor within ten minutes post-mortem. The carcass was chilled for twenty-four hours at $3{ }^{\circ} \mathrm{C}-4^{\circ}$ Cusing cold room and reweighed to get chilled carcass weight, allowed to thaw for twelve hours at room temperature and dimensional measurements: carcass length, length of hindquarters, length of fore-quarters, and depth of chest according to the procedures of De Boer et al. [7].Dissection of carcasses commenced after thawing. The left sides were separated as outlined by Fisher and De Boer [7]. The lengths of the pistol were obtained following quartering of the carcass side.

\subsection{Dissection of Muscles}

The abdominal muscles were freed where they join the pelvic limb and the side was cut along the edge of Iliocostalis lumborum muscle through the ribs to the earlier cut between the $5^{\text {th }}$ and6th thoracic vertebrae [9] and then the cut was continued along the caudal edge of the $5^{\text {th }}$ rib. This divided the side into a pistol hindquarter and a pistol forequarter. The right pistol hindquarter and pistol forequarter were weighed and dissected into individual lmuscles (semimembranosus, semitendinosus, bicepsfemoris, adductor, gluteus medius, deltoideus, supraspinatus, infraspinatus, subscapularis, and deltodius), bones and fat following the procedures of Robelin and Geay [10]. Values were expressed as a percentage of the pistol weight.

\subsection{Derived Indexes}

Body measurements to liveweight $(\mathrm{cm} / 100 \mathrm{~g})$, hot carcass 
weight to carcass measurements $(\mathrm{cm} / 100 \mathrm{~g})$, and the proportion of individual muscles to pistol weight were recorded based on standard procedure [11]. Also proportion of bone distribution to pistol weight, Proportion of fat distribution to pistol weight, relationship between hot carcass weight and percentage proportion of individual muscles were obtained according to Purchas et al. [12].

\subsection{Statistical Analyses}

Data were statistically analyzed using one-way analysis of variance, the procedure of the Statistical Analysis System [13]. The LSD procedure was applied for mean comparison at $5 \%$. Simple correlation coefficients of hot carcass weight and proportional weight of tissues of the proximal hindquarter and proximal forequarter of the carcasses were carried out using Pearson's correlations.

\section{Results and Discussion}

\subsection{Body Measurements}

Linear measurements of Balami, Ouda, Yakansa and West African Dwarf rams intensively fattened are shown in Table1. There were statistical variations $(\mathrm{P}<0.05)$ in all the parameters measured except liveweight and chest width that ranged from $36.39-37.00 \mathrm{~kg}$ and $17.75-19.25 \mathrm{~cm}$. BA $(115.75 \pm 4.25,70.50 \pm 5.57$ and $92.00 \pm 2.94 \mathrm{~cm})$ and UD $(110.25 \pm 1.89, \quad 69.00 \pm 2.16$ and $84.00 \pm 1.41 \mathrm{~cm})$ had significantly higher values than YK $(96.50 \pm 3.87,60.75 \pm 3.30$ and $76.75 \pm 0.96 \mathrm{~cm})$ and WAD $(86.50 \pm 5.20,53.25 \pm 5.32$ and $75.25 \pm 3.30 \mathrm{~cm}$ ) for body length wither height and heart girth and the values for YK were greater than WAD rams, respectively. BA had a significant pelvic chest than UD $(80.25 \pm 5.80)$ and WAD $(61.00 \pm 2.94)$, which were not different $(\mathrm{P}>0.05)$. When expressed relative to liveweight, $\mathrm{BA}$ and WAD rams differed significantly for all values, whereas UD $(84.00 \pm 1.41$ and $80.25 \pm 5.80)$ had significantly higher values for heart girth and pelvis height than WAD (75.25 \pm 3.30 and $61.00 \pm 2.94)$. The effect of slaughter weight on carcass measurements indicated that all carcass measurements increased $(\mathrm{P}<0.05)$ with the increase of slaughter weight. The slaughter weight in the present study reflects commercial practices and maintains good comparability with other breeds. Lavvaf et al. [14] observed that chest girth and rump width were suitable factors for predicting hot carcass weight in each of Afshari and Zandi sheep, respectively. Also, body measurements are important data sources in terms of reflecting the breed standards [15], and giving information about the morphological structure and development ability of the animals.

Table1. Morphometric Measurements and relative measurements to liveweight of four breeds of rams intensively fattened.

\begin{tabular}{|c|c|c|c|c|}
\hline Parameters & BA & UD & YK & WAD \\
\hline Live weight (kg) & $36.59 \pm 1.83$ & $37.00 \pm 0.82$ & $36.00 \pm 1.83$ & $36.39 \pm 2.38$ \\
\hline \multicolumn{5}{|c|}{ Measurements (cm) } \\
\hline Wither heigth & $70.50 \pm 5.57^{\mathrm{a}}$ & $69.00 \pm 2.16^{\mathrm{a}}$ & $60.75 \pm 3.30^{\mathrm{b}}$ & $53.25 \pm 5.32^{\mathrm{c}}$ \\
\hline Heart girth & $92.00 \pm 2.94^{\mathrm{a}}$ & $84.00 \pm 1.41^{\mathrm{a}}$ & $76.75 \pm 0.96^{\mathrm{c}}$ & $75.25 \pm 3.30^{c}$ \\
\hline Pelvis height & $88.00 \pm 2.16^{\mathrm{a}}$ & $80.25 \pm 5.80^{b}$ & $71.50 \pm 2.65^{\mathrm{c}}$ & $61.00 \pm 2.94^{\mathrm{d}}$ \\
\hline Chest width & $18.75 \pm 0.50$ & $19.25 \pm 0.50$ & $17.75 \pm 1.71$ & $17.75 \pm 3.30$ \\
\hline Chest depth & $33.00 \pm 2.58^{\mathrm{a}}$ & $33.00 \pm 3.74^{\mathrm{a}}$ & $29.50 \pm 2.65^{\mathrm{ab}}$ & $25.75 \pm 0.96^{\mathrm{b}}$ \\
\hline \multicolumn{5}{|c|}{ Measurements relative to live weight $(\mathrm{cm} / 100 \mathrm{~g})$} \\
\hline Body length & $3.17 \pm 0.16^{\mathrm{a}}$ & $2.98 \pm 0.11^{\mathrm{ab}}$ & $2.77 \pm 0.23^{b}$ & $2.76 \pm 0.26^{b}$ \\
\hline Wither heigth & $1.93 \pm 0.09^{\mathrm{a}}$ & $1.87 \pm 0.03^{\mathrm{ab}}$ & $1.74 \pm 0.16^{\mathrm{ab}}$ & $1.70 \pm 0.20^{\mathrm{b}}$ \\
\hline Heart girth & $2.52 \pm 0.07^{\mathrm{a}}$ & $2.27 \pm 0.06^{\mathrm{ab}}$ & $2.20 \pm 0.12^{\mathrm{bc}}$ & $2.40 \pm 0.17^{\mathrm{c}}$ \\
\hline Chest width & $0.51 \pm 0.04$ & $0.52 \pm 0.02$ & $0.51 \pm 0.07$ & $0.57 \pm 0.11$ \\
\hline Chest depth & $0.09 \pm 0.07$ & $0.89 \pm 0.10$ & $0.85 \pm 0.09$ & $0.82 \pm 0.08$ \\
\hline
\end{tabular}

Means in the same row with different superscripts are significantly different $(\mathrm{P}<0.05)$. BA: Balami, UD: Ouda, YK: Yankasa, WAD: West African Dwarf

\subsection{Carcass Measurements}

Table 2 summarized the carcass measurements and distribution of tissues within the proximal hindquarters and forequarters. The proportion of hot carcass weight was $18.72 \pm 1.85,18.25 \pm 0.87,17.72 \pm 0.17$ and $17.72 \pm 1.26$ for BA, $\mathrm{UD}, \mathrm{YK}$, and WAD, respectively. Pistola weights of the hindquarter and forequarter were significantly greater for BA $(74.00 \pm 4.36 ; 61.67 \pm 7.10)$ and UD $(68.00 \pm 6.25 ; 60.67 \pm 2.60)$ than YK $(62.67 \pm 4.16 ; 54.67 \pm 7.23)$ which in turn was greater than WAD $(50.00 \pm 3.61 ; 49.00 \pm 3.61)$. When expressed relative to hot carcass weight, carcass length, carcass depth, hindquarters, forequarters, and Pistola lengths did not differ $(\mathrm{P}>0.05)$ between the breeds but the lowest were recorded $(\mathrm{P}<0.05)$ for WAD. All the four breeds differed significantly for lengths of hindquarters and forequarters relative to carcass weight, which was greatest for BA $(0.47 \pm 0.04$; $0.33 \pm 0.01)$ and least for WAD $(0.34 \pm 0.02 ; 0.28 \pm 0.01)$. Carcass measurements and indexes are used as indicators of carcass conformation and size [16]. The results of the current study indicate a significant effect of breed on carcass measurements and conformation indexes, which could be explained by breed specific morphologic characteristics of 
BA rams.

Table 2. Hot carcass weight and carcass measurements of four breeds of rams intensively fattened.

\begin{tabular}{|c|c|c|c|c|}
\hline Parameters & BA & UD & YK & WAD \\
\hline Hot Carcass Weight & $18.72 \pm 1.85$ & $18.25 \pm 0.87$ & $17.72 \pm 0.17$ & $17.72 \pm 1.26$ \\
\hline \multicolumn{5}{|l|}{ Carcass Measurements (cm) } \\
\hline Carcass Length & $75.75 \pm 4.79^{\mathrm{a}}$ & $75.50 \pm 4.66^{\mathrm{a}}$ & $59.00 \pm 7.79^{\mathrm{b}}$ & $60.50 \pm 3.11^{\mathrm{b}}$ \\
\hline Carcass Depth & $24.25 \pm 0.96$ & $24.50 \pm 0.58$ & $24.75 \pm 3.30$ & $24.25 \pm 4.03$ \\
\hline Hindquarter Length & $88.00 \pm 2.16^{\mathrm{a}}$ & $80.25 \pm 5.80^{\mathrm{b}}$ & $71.50 \pm 2.65^{\mathrm{c}}$ & $61.00 \pm 2.94^{\mathrm{d}}$ \\
\hline Pistola Hindquarter Length & $74.00 \pm 4.36^{\mathrm{a}}$ & $68.00 \pm 6.25^{\mathrm{ab}}$ & $62.67 \pm 4.16^{\mathrm{b}}$ & $50.00 \pm 3.61^{\mathrm{c}}$ \\
\hline Forequarter Length & $70.30 \pm 6.81^{\mathrm{a}}$ & $69.00 \pm 2.65^{\mathrm{a}}$ & $64.00 \pm 8.55^{\mathrm{ab}}$ & $55.33 \pm 4.04$ \\
\hline Pistola Forequarter Length & $61.67 \pm 7.10^{\mathrm{a}}$ & $60.67 \pm 25.89^{\mathrm{a}}$ & $54.67 \pm 7.23^{\mathrm{ab}}$ & $49.00 \pm 3.61^{\mathrm{b}}$ \\
\hline \multicolumn{5}{|c|}{ Carcass Measurements (cm/100g carcass) } \\
\hline Carcass Length & $0.41 \pm 0.02^{\mathrm{a}}$ & $0.42 \pm 0.02^{\mathrm{a}}$ & $0.34 \pm 0.04^{\mathrm{b}}$ & $0.39 \pm 0.05^{\mathrm{ab}}$ \\
\hline Carcass Depth & $0.13 \pm 0.01$ & $0.14 \pm 0.01$ & $0.14 \pm 0.02$ & $0.15 \pm 0.01$ \\
\hline Hindquarter Length & $0.47 \pm 0.04^{\mathrm{a}}$ & $0.44 \pm 0.02^{\mathrm{ab}}$ & $0.40 \pm 0.03^{\mathrm{b}}$ & $0.34 \pm 0.01^{\mathrm{c}}$ \\
\hline Pistola Hindquarter Length & $0.40 \pm 0.04^{\mathrm{a}}$ & $0.37 \pm 0.02^{\mathrm{ab}}$ & $0.34 \pm 0.02^{\mathrm{b}}$ & $0.28 \pm 0.01^{\mathrm{c}}$ \\
\hline Forequarter Length & $0.38 \pm 0.02^{\mathrm{a}}$ & $0.38 \pm 0.04^{\mathrm{a}}$ & $0.35 \pm 0.03^{\mathrm{ab}}$ & $0.31 \pm 0.02^{\mathrm{b}}$ \\
\hline Pistola Forequarter Length & $0.33 \pm 0.01^{\mathrm{a}}$ & $0.33 \pm 0.0^{4 a}$ & $0.30 \pm 0.03^{\mathrm{ab}}$ & $0.28 \pm 0.01^{\mathrm{b}}$ \\
\hline
\end{tabular}

Means in the same row with different superscripts are significantly different $(\mathrm{P}<0.05)$. BA: Balami, UD: Ouda,YK: Yankasa, WAD: West African Dwarf

\subsection{Meat to Bone Ratio}

Weight to length ratio has been proposed as an objective measure of the carcass index. This index describes the amount of meat and fat which a carcass carries relative to its length and affords a quick and accurate description of its meatiness [17]. Proportions of tissues in the carcass of the four breeds of rams intensively fattened are shown in Table3. The meat to bone ratio as determined by dissection of the proximal hindquarter and proximal forequarter of the left half of the carcass were 8.92 and 12.90 in BA and 5.81 and 12.64 in UD, respectively and the corresponding ratio for $\mathrm{YK}$ and WAD were $5.46 ; 7.92$ and $4.88 ; 10.10$, respectively. BA had the highest $(\mathrm{P}<0.05)$ meat to bone ratio due to its lowest fat proportion. UD, YK, and WAD yielded similar meat to the bone ratio $(\mathrm{P}>0.05)$ while $\mathrm{BA}$, UD, and WAD breeds had similar meat to fat ratios. Differences in carcass were primarily due to the distribution of fat and to variation in the thickness of muscles but not differences in muscle distribution. The sequence of growth illustrates the importance of each fat depot in animals and the market value of the carcass [18]. Cloete et al. [19] observed differences in the fat deposition of mutton breeds which suggests that different breeds would deposit fat at different levels. Early matured breeds would render a fatter carcass at slaughter, after a constant number of days in the feed [20], which in turn would affect the value of the carcass. It is therefore important to determine the maturation rate of the major carcass tissues of various breeds of sheep to accurately predict a slaughter weight for ideal grading of the carcass. Using a commercial dissection procedure, Colomer-Rocheret al. [21] found that hindquarter cuts had more muscle and a higher muscle-to-bone ratio than those in forequarter cuts.

Table 3. Proportional Percentage of Muscle, Bone and Fat to the Pistola Weight of the Hindlegs and Forelegs of four breeds of rams intensively fattened $( \pm S T D)$.

\begin{tabular}{|c|c|c|c|c|}
\hline \multicolumn{5}{|l|}{ Breeds } \\
\hline Parameters & BA & UD & YK & WAD \\
\hline Pistola Weight of Hindleg & $4.72 \pm 0.58^{\mathrm{a}}$ & $5.35 \pm 0.19^{\mathrm{ab}}$ & $4.04 \pm 1.09^{\mathrm{ab}}$ & $4.67 \pm 0.35^{\mathrm{b}}$ \\
\hline Pistola Weight of Foreleg & $2.26 \pm 0.32$ & $2.81 \pm 0.21$ & $2.49 \pm 0.50$ & $2.64 \pm 0.45$ \\
\hline \multicolumn{5}{|l|}{ Muscle distribution $(\mathrm{g} / \mathrm{kg})$} \\
\hline Pistola Muscles of Hindquarter & $82.48 \pm 0.01^{\mathrm{a}}$ & $82.44 \pm 3.74^{\mathrm{a}}$ & $72.88 \pm 4.11^{\mathrm{b}}$ & $77.71 \pm 0.89^{\mathrm{ab}}$ \\
\hline Pistola Muscles of Foreleg & $82.18 \pm 0.01^{\mathrm{a}}$ & $76.97 \pm 3.09^{\mathrm{ab}}$ & $73.79 \pm 4.97^{\mathrm{b}}$ & $72.22 \pm 6.53^{b}$ \\
\hline \multicolumn{5}{|l|}{ Bone distribution (g/kg) } \\
\hline Pistola Bones of Foreleg & $9.43 \pm 0.02^{\mathrm{b}}$ & $15.33 \pm 2.74^{\mathrm{a}}$ & $14.15 \pm 1.62^{\mathrm{ab}}$ & $13.08 \pm 4.01^{\mathrm{ab}}$ \\
\hline \multicolumn{5}{|l|}{ Fat distribution (g/kg) } \\
\hline Pistola Fat of Hindquarter & $7.12 \pm 0.06^{\mathrm{b}}$ & $5.24 \pm 1.38^{\mathrm{b}}$ & $8.23 \pm 3.04^{\mathrm{ab}}$ & $11.49 \pm 1.89^{\mathrm{a}}$ \\
\hline Pistola Fat of Foreleg & $5.64 \pm 0.03$ & $5.37 \pm 1.87$ & $6.68 \pm 0.37$ & $7.61 \pm 2.18$ \\
\hline Meat: Bone & $8.92 \pm 0.01^{\mathrm{a}}$ & $5.81 \pm 0.04^{\mathrm{b}}$ & $5.46 \pm 1.01^{\mathrm{b}}$ & $4.88 \pm 0.97^{\mathrm{b}}$ \\
\hline Meat: Fat & $12.90 \pm 0.03^{\mathrm{a}}$ & $12.64 \pm 0.28^{\mathrm{a}}$ & $7.92 \pm 2.52^{\mathrm{b}}$ & $10.10 \pm 2.00^{\mathrm{ab}}$ \\
\hline
\end{tabular}

Means in the same row with different superscripts are significantly different $(\mathrm{P}<0.05)$. BA: Balami, UD: Ouda, YK: Yankasa, WAD: West African Dwarf

\subsection{Muscle Measurements of the Pistola Hindquarters and Forequarters}

The distribution of muscles in intensively fattened Balami, Ouda, Yankasa and West African Dwarf rams is shown in
Table4. The highest value $(\mathrm{P}<0.05)$ of semimembranosus was recorded for $\mathrm{BA}(0.54 \pm 0.02)$ and while the least was recorded for WAD $(0.47 \pm 0.03)$. The proportional values measured values for Ouda $(0.51 \pm 0.08)$ and Yankasa 
$(0.45 \pm 0.01)$ in the semimembranosus muscle were higher $(\mathrm{P}<0.05)$ than Balami $(0.39 \pm 0.03)$ and West African Dwarf rams $(0.38 \pm 0.02)$. Results showed that Ouda $(0.38 \pm 0.03)$ had the highest Adductor muscle (\%), followed by Yankasa $(0.37 \pm 0.01 \%)$ while Balami $(0.33 \pm 0.01)$ and WAD breeds $(0.32 \pm 0.04)$ showed the lowest. The percentage proportion of Gluteus Medius muscle was higher in Ouda $(0.14 \pm 0.01)$ when compared to Yankasa $(0.13 \pm 0.01)$, but not significant when compared to Balami $(0.13 \pm 0.01)$ and WAD $(0.12 \pm 0.01)$. The proportional weight of gluteus medius was lower for YK $(0.15 \pm 0.01)$ and WAD $(0.15 \pm 0.02)$ than BA $(0.18 \pm 0.01)$ and UD $(0.17 \pm 0.01)$, which were similar $(\mathrm{P}>0.05)$. The weight of deep pectoralis was higher for BA $(0.63 \pm 0.06)$ than UD $(0.42 \pm 0.11)$, YK $(0.38 \pm)$ and WAD $(0.42 \pm 0.17)$, which were not significant to one another $(\mathrm{P}>0.05)$. The weights of infraspinatus $(0.23 \pm 0.01)$, supraspinatus $(0.18 \pm 0.05)$, deltoideus $(0.30 \pm 0.02)$ and subscapularis $(0.24 \pm 0.08)$ were significantly greater for BA. The corresponding weights of infraspinatus $(0.18 \pm 0.04)$, supraspinatus $(0.13 \pm 0.01)$, deltoideus $(0.25 \pm 0.02)$, and subscapularis $(0.27 \pm 0.10)$ were not significantly different $(\mathrm{P}>0.05)$ for WAD rams. The relative weight of the semimembranosus was significantly higher for UD $(0.51 \pm 0.08)$ and YK $(0.45 \pm 0.01)$ than for BA $(0.39 \pm 0.03)$ and WAD $(0.38 \pm 0.02)$. The relative weight of the Semitendinosus muscle (0.40 \pm 0.04$)$, Adductor (0.38 \pm 0.03$)$, Gluteusmedius $(0.14 \pm 0.01)$ and Bicep femoris $(0.34 \pm 0.04)$ were significantly higher for Ouda than the values recorded for both BA and YK. With increasing slaughter weight, muscle weight increased significantly for semimembranosus, semitendinosus, gluteus medius bicep femoris, deep pectoralis, infraspinatus, supraspinatus, deltoideus and subscapularis, All relative measurements decreased significantly for BA except for deep pectoralis, infraspinatus, and supraspinatus, which did not differ $(\mathrm{P}>0.05)$ between the slaughter weights. The greater muscle of BA compared to the UD, YK and WAD breeds reflected the fleshiness and carcass size. An increase in carcass weight increased the values of all carcass measurements but when expressed relative to carcass weight they were reduced, indicating greater carcass compactness. The relatively small differences in tissue distribution together with the significant differences in the proportion of muscle in the weight suggest that carcass weight is a reliable indicator of economic traits. Lodge [22] suggested that the superior performance of local sheep is due to the results that they have the potential to respond to better management.

Table 4. Hot carcass weight and percentage proportion of muscles of four breeds of rams intensively fattened.

\begin{tabular}{lllll}
\hline Breeds & & & & \\
\hline Parameters & BA & UD & YK & WAD \\
\hline Hot Carcass Weigth & $18.72 \pm 1.85$ & $18.25 \pm 0.87$ & $17.72 \pm 0.17$ & $16.82 \pm 1.26$ \\
Muscle Measurements (g) & & & \\
Semimembranosus & $0.54 \pm 0.02^{\mathrm{ab}}$ & $0.59 \pm 0.10^{\mathrm{a}}$ & $0.49 \pm 0.01^{\mathrm{b}}$ & $0.47 \pm 0.03^{\mathrm{b}}$ \\
Semitendinosus & $0.49 \pm 0.14^{\mathrm{a}}$ & $0.46 \pm 0.02^{\mathrm{ab}}$ & $0.37 \pm 0.02^{\mathrm{ab}}$ & $0.35 \pm 0.06^{\mathrm{b}}$ \\
Adductor & $0.47 \pm 0.06$ & $0.45 \pm 0.03$ & $0.40 \pm 0.01$ & $0.40 \pm 0.05$ \\
GluteusMedius & $0.18 \pm 0.01^{\mathrm{a}}$ & $0.17 \pm 0.01^{\mathrm{ab}}$ & $0.15 \pm 0.01^{\mathrm{c}}$ & $0.15 \pm 0.02^{\mathrm{bc}}$ \\
Bicepsfemoris & $0.36 \pm 0.01^{\mathrm{a}}$ & $0.39 \pm 0.06^{\mathrm{a}}$ & $0.25 \pm 0.05^{\mathrm{b}}$ & $0.22 \pm 0.06^{\mathrm{b}}$ \\
Deeppectoralis & $0.63 \pm 0.06^{\mathrm{a}}$ & $0.42 \pm 0.11^{\mathrm{b}}$ & $0.38 \pm 0.02^{\mathrm{b}}$ & $0.42 \pm 0.17^{\mathrm{b}}$ \\
Infraspinatus & $0.23 \pm 0.01^{\mathrm{a}}$ & $0.19 \pm 0.01^{\mathrm{b}}$ & $0.18 \pm 0.01^{\mathrm{b}}$ & $0.18 \pm 0.04^{\mathrm{b}}$ \\
Supraspinatus & $0.18 \pm 0.05^{\mathrm{a}}$ & $0.14 \pm 0.01^{\mathrm{b}}$ & $0.14 \pm 0.01^{\mathrm{b}}$ & $0.13 \pm 0.01^{\mathrm{b}}$ \\
Deltoideus & $0.30 \pm 0.02^{\mathrm{a}}$ & $0.27 \pm 0.01^{\mathrm{ab}}$ & $0.28 \pm 0.02^{\mathrm{ab}}$ & $0.25 \pm 0.02^{\mathrm{b}}$ \\
Subscaplaris & $0.24 \pm 0.08^{\mathrm{ab}}$ & $0.17 \pm 0.09^{\mathrm{b}}$ & $0.31 \pm 0.01^{\mathrm{a}}$ & $0.27 \pm 0.10^{\mathrm{ab}}$ \\
Percentage proportion of muscle to HCW & & & \\
Semimembranosus & $0.39 \pm 0.03^{\mathrm{bc}}$ & $0.51 \pm 0.08^{\mathrm{a}}$ & $0.45 \pm 0.01^{\mathrm{ab}}$ & $0.38 \pm 0.02^{\mathrm{c}}$ \\
Semitendinosus & $0.34 \pm 0.06^{\mathrm{ab}}$ & $0.40 \pm 0.04^{\mathrm{a}}$ & $0.34 \pm 0.02^{\mathrm{ab}}$ & $0.28 \pm 0.04^{\mathrm{b}}$ \\
Adductor & $0.33 \pm 0.01^{\mathrm{bc}}$ & $0.38 \pm 0.03^{\mathrm{a}}$ & $0.37 \pm 0.01^{\mathrm{ab}}$ & $0.32 \pm 0.04^{\mathrm{c}}$ \\
GluteusMedius & $0.13 \pm 0.01^{\mathrm{bc}}$ & $0.14 \pm 0.01^{\mathrm{a}}$ & $0.13 \pm 0.00^{\mathrm{b}}$ & $0.12 \pm 0.01^{\mathrm{c}}$ \\
Bicepsfemoris & $0.25 \pm 0.01^{\mathrm{b}}$ & $0.34 \pm 0.04^{\mathrm{a}}$ & $0.24 \pm 0.05^{\mathrm{bc}}$ & $0.18 \pm 0.04^{\mathrm{c}}$ \\
Deeppectoralis & $0.45 \pm 0.09$ & $0.37 \pm 0.11$ & $0.35 \pm 0.01$ & $0.34 \pm 0.13$ \\
Infraspinatus & $0.17 \pm 0.01$ & $0.16 \pm 0.01$ & $0.17 \pm 0.01$ & $0.13 \pm 0.01$ \\
Supraspinatus & $0.13 \pm 0.04$ & $0.12 \pm 0.00$ & $0.26 \pm 0.02^{\mathrm{a}}$ & $0.11 \pm 0.01$ \\
Deltoideus & $0.21 \pm 0.01^{\mathrm{bc}}$ & $0.23 \pm 0.00^{\mathrm{b}}$ & $0.20 \pm 0.02^{\mathrm{c}}$ \\
Subscaplaris & $0.17 \pm 0.04^{\mathrm{b}}$ & $0.22 \pm 0.06^{\mathrm{ab}}$ & $0.27 \pm 0.01^{\mathrm{a}}$ \\
\hline
\end{tabular}

Means in the same row with different superscripts are significantly different $(\mathrm{P}<0.05)$. BA: Balami, UD: Ouda, YK: Yankasa, WAD: West African Dwarf

\subsection{Relationship Between Hot Carcass Weight and Muscle Distribution}

Significant positive correlations $(\mathrm{P}<0.05)$ were obtained between hot carcass weight and Semitendinosus muscle (0.89) and Supraspinatus muscle (0.56), whereas a high negative correlation $(\mathrm{P}<0.05)$ was obtained with Subscapularis muscle (0.34). Significant positive correlations were obtained between Semitendinosus muscle and Bicep femoris muscle (0.58), Adductor muscle (0.88), Gluteus medius (0.83), Infraspinatus (0.67) and Deltodius (0.66), 
whereas significant negative correlations were obtained with Subscapularis muscle and Bicep femoris muscle (0.50), Semimembranosus muscle (0.37), Adductor muscle (0.97), Deep pectoralis muscle (0.54) and Supraspinatus muscle (0.73) proportions. Correlation coefficients between Semimembranosus muscle and Bicep femoris muscle (0.84), Adductor muscle (0.68) and Gluteus medius (0.64) were in the same direction of those obtained from Bicep femoris muscle with Adductor muscle (0.61) and Gluteus medius (0.71) value. Correlations between the muscles of the carcass appear more dependent upon hindlegs and forelegs rather than an absolute hot carcass weight. This is evidenced by the fact that the highest correlations were seen between the muscles of the foreleg (supraspinatus and infraspinatus, Deep pectoralis and Deltoideus muscles) and the hindleg (semimembranosus and semitendinosus, Adductor and Gluteus medius muscles). The relationship between hot carcass weight and the distribution of muscles suggests that an increase in one could lead to a corresponding increase in the other muscles [23, 24].

Table 5. Pearson Correlation coefficients between hot carcass weight and percentage proportion of muscles of carcasses of Balami, Ouda, Yankasa and West African Dwarf rams intensively fattened.

\begin{tabular}{|c|c|c|c|c|c|c|c|c|c|c|c|}
\hline & HCW & ST & SM & BF & ADD & GM & DP & IF & SS & DT & SCP \\
\hline $\mathrm{HCW}$ & 1 & $0.89 *$ & $0.52^{\mathrm{ns}}$ & $0.29^{\text {ns }}$ & $0.77^{\mathrm{ns}}$ & $0.67^{\mathrm{ns}}$ & $0.48^{\text {ns }}$ & $0.39^{\text {ns }}$ & $0.56^{*}$ & $0.32^{\text {ns }}$ & $-0.34^{\mathrm{ns}}$ \\
\hline ST & & 1 & $0.42^{\mathrm{ns}}$ & $0.58 *$ & $0.88 * * *$ & $0.83 * * *$ & $0.38^{\mathrm{ns}}$ & $0.67 * *$ & $0.79^{\mathrm{ns}}$ & $0.66^{* *}$ & $0.80^{\mathrm{ns}}$ \\
\hline SM & & & 1 & $0.84 * * *$ & $0.68 * *$ & $0.64 * *$ & $0.42^{\text {ns }}$ & $0.43^{\mathrm{ns}}$ & $0.33^{\text {ns }}$ & $0.29^{\mathrm{ns}}$ & $-0.37^{\mathrm{ns}}$ \\
\hline $\mathrm{BF}$ & & & & 1 & $0.61^{* *}$ & $0.71 * *$ & $0.37^{\mathrm{ns}}$ & $0.36^{\mathrm{ns}}$ & $0.32^{\text {ns }}$ & $0.41^{\mathrm{ns}}$ & $-0.50^{*}$ \\
\hline ADD & & & & & 1 & $0.88 * * *$ & $0.54 *$ & $0.67 * *$ & $0.43^{\mathrm{ns}}$ & $0.63^{* *}$ & $-0.97 * *$ \\
\hline GM & & & & & & 1 & $0.55^{*}$ & $0.75 * * *$ & $0.39^{\mathrm{ns}}$ & $0.54^{*}$ & $-0.60^{\mathrm{ns}}$ \\
\hline IF & & & & & & & & 1 & $0.57^{*}$ & $0.78 * * *$ & $0.49^{\text {ns }}$ \\
\hline SS & & & & & & & & & 1 & 0.37 & $-0.73^{\text {ns }}$ \\
\hline DT & & & & & & & & & & 1 & $0.42^{\mathrm{ns}}$ \\
\hline SCP & & & & & & & & & & & 1 \\
\hline
\end{tabular}

HCW: Hot carcass Weight, ST: Semitendinosus muscle, SM; Semimembranosus muscle, BF: Bicep femoris, ADD; Adductor, GM: Gluteus medius, DP: Deep pectoralis, IF: Infraspinatus, SS: Supraspinatus, DT: Deltoideus, SCP: Subscapularis, Significanct levels: $* * * \mathrm{P}<0.001, * * \mathrm{P}<0.01, * \mathrm{P}<0.05$

\section{Conclusions}

Differences between breeds were observed in the morphology of the carcass and muscles of four breeds of rams intensively fattened. Yankasa and West African Dwarf breeds of rams had lower carcass measurements than Balami and Ouda breeds. The combination of morphological traits and distribution of muscles found in the carcasses for the Balami breeds of rams in this study indicated that this breed would most likely produce the best carcass under similar agricultural conditions. The study also concludes that the measurements of the muscles of the hindlegs and forelegs could be used satisfactorily for prediction of hot carcass weight.

\section{Acknowledgements}

The authors are grateful to the Management of the University of Ibadan, Ibadan, Nigeria for the use of its facilities at the Teaching and Research Farm and the Meat Science Laboratory during the research.

\section{Conflict of Interest}

The authors declare that they have no conflict of interest.

\section{Funding Status}

This research did not receive any specific grant from funding agencies in the public and profit sectors.

\section{References}

[1] Agboola, M. O and Balcilar M. (2012). Impact of Food Security on Urban Poverty: A Case Study of Lagos State, Nigeria. Procedia-Social and Behavioral Sciences. Vol62 (1995): 1225-1229.

[2] Karim, S. A. and Rawat, P. S. (1997). Growth performance and carcass characteristics of lambs raised on varying levels of roughage and concentrate. Indian J. Anim. Sci. 67: 902-905.

[3] Hernández-Castellano L. E, Morales-dela Nuez A, MorenoIndias I, Torres A, Sánchez-Macias D, Capote J, Castro N, Argüello A. (2013). Carcass and meat quality determination as a tool to promote local meat consumption in outer most regions of Europe. J Appl Anim Res. 41: 269-276.

[4] Yakubu, A. (2010). Fixing multi collinearity instability in the prediction of body weight from morphometric traits of White Fulani cows. J. Cent. Eur. Agr., 11 (4): 487-92.

[5] Bee, G, Anderson, A. L, Lonergan, S. M, Huff-Lonergan, E. (2007) Rate and extent of $\mathrm{Ph}$ decline affect proteolysis of cytoskeletal proteins and water-holding capacity in pork. Meat Science 76, 359-365.

[6] Srivastava, V. K, Raizada, B. O. And Kulkarni, V. A (1968). Carcass quality of Barbari and Jamnapari type goats. Indian Veterinary Journal 45: 219-225.

[7] De Boer, H.,B. L. Dumont, R. W. Pomeroy, and J. H. Weniger. (1974). Reference method for the assessment of carcass characteristics in cattle. Manual on E. A. A. P. Livest. Prod. Sci. 1: 151-164. 
[8] MS1500. (2009). Halal food. Production, preparation, handling and storage general guideline. Department of Standards Malaysia; p.1-13.

[9] Williams, D. R. And Bergström, P. L. (1980). Anatomical Jointing, Tissue Separation and Weight Recording: E E C Standard Method for Beef, Commission of the European Communities, Brussels Eur 6878 E N, ISBN 070841716.

[10] Robelin, J. and Geay, Y. (1975). Estimation dela composition dela carcasse destaurillon sápartir dela composition dela 6 acôte. Bull. Tech. CRZVINRATheix22, 41-43.

[11] Purchas, R. W, Davies, A. S, Abdullah, A. Y. (1991). An objective measure of muscularity: changes with animal growth and differences between genetic lines of Southdown sheep. Meat Science, v.30, p.81-94.

[12] Purchas, R. W., Morris, S. T. \& Grant, D. A., (1992). A comparison of characteristics of the carcasses from Friesian, Piedmontese X Friesian, and Belgian Blue X Friesian bulls. N. Z.J. Agric. Res. 35, 401-409.

[13] Statistical Analysis Systems Institute (1999). SAS/STAT. The SAS system for windows, Release 6. 12, SAS Institute Inc., Cary, N C, USA.

[14] Lavvaf, A., Noshari A and Farahvash, T. (2012). Evaluation of the relationship between body measurements and carcass traits of finishing afshari and zandi rams. Asian J. Anim. Vet. Adv., 7: 187-192.

[15] Riva, J., Rizzi, R., Marelli, S., Cavalchini, G. (2002). Body Measurements in Bergamasca Sheep, Small Ruminant Research, 221-227.

[16] Sañudo, C., Sanchez, A., and Alfonso, M. (1980c). Small ruminant production systems and factors affecting lamb meat quality. Meat Science, 49 (Suppl.1), 29-64.
[17] Thwaites C. J, Yeates N. T. M, Pogue R. F. (1964). Objective appraisal of intact lamb and mutton carcasses. J Agric Sci. 63: 415-420.

[18] Negussie, E., Rottmann, O. J., Pirchner, F. And Rege, J. E. O., (2003). Patterns of growth and partitioning of fat depots in tropical fat-tailed Menz and Horro sheep breeds. Meat Sci. 64, 491-498.

[19] Cloete, J. J. E, Hoffman, L. C, Cloete, S. W. P. (2012). A comparison between slaughter traits and meat quality of various sheep breeds: Wool, dual-purpose and mutton. Meat Sci; 91: 318-24.

[20] Berg, R., and Walters, L., (1983). The meat animal: Changes and challenges. J. Anim. Sci. 57, 133-146.

[21] Colomer-Rocher F, Bass, J. J and Johnson, D. L (1980). Beef carcass conformation and some relationship with carcass composition and muscle dimensions. Journal of Agricultural Science, Cambridge 94, 697-708.

[22] Lodge, G. A. (1989). The University experience and perspective. First International Symposium on Agriculture and Fisheries Development in Oman. Ministry of Agriculture and Fisheries and Sultan Qaboos University, Muscat.

[23] Assan, N (2013) Bio prediction of body weight and carcass parameters from morphometric measurements in livestock and poultry. Sci J Rev 2: 140-150.

[24] Abbasi, M. A. and Ghafouri-Kesbi, F. (2011) Genetic (co) variance components for body weight and body measurements in Makooei Sheep.Asian-Australian Journal of Animal Science 24 (6): 739-743. 